\title{
INTRODUCTION OF INNOVATIONS IN THE TOURISM INDUSTRY: EXPERIENCE OF UKRAINE
}

\author{
Donysche-Medyanik Alla \\ Candidate of Sciences (Economics), Associate Professor, \\ Uzhhorod Institute of Trade and Economics \\ of Kyiv National University of Trade and Economics \\ medyanik_alla@mail.ru \\ Klyap Mykhaylo \\ Candidate of Sciences (Physics and Mathematics), Associate Professor, \\ Deputy Director of the Uzhhorod Institute of Trade and Economics \\ of Kyiv National University of Trade and Economics \\ m_klyop@ukr.net
}

(Received November 2016; Accepted February 2017)

\begin{abstract}
The article deals with relevance and necessity of studying innovative processes in tourism industry as an important indicator of tourism development in the modern market conditions. Formulated and substantiated directions of innovative technologies introduction in the hospitality industry of Ukraine. Conducted research and substantiated principles of innovations in tourism and the processes in use of advanced services: Sleepbox, multimedia digital technologies Digital Signage, new technologies "Teleport" from the hotel network "Marriott". Suggested a few ways to improve the service economy.
\end{abstract}

Key words: innovations, innovative processes, tourism industry, hotel and restaurant business, information technology, geo-targeting, eco-concept.

Introduction. Ukraine is going through difficult times. In connection with the events in the East of Ukraine, Crimea annexation is a significant redistribution of tourist flows. Increasing the attractiveness of the Carpathian region of Ukraine that borders with the European Union countries: Romania, Hungary, Slovak Republic and Poland. Through this study and implementation of innovative technologies in tourism is actual in the context of increased international cooperation.

Also know that in difficult crisis moments the economy is favorable for innovations. About this, in the middle of the XX century, said H. Mensh $(\mathrm{H}$. Mensh, 1979) and called this interconnection "trigger effect of depression", meaning that it is depression launches innovative process. H. Mensh also noted that the innovative process is not uniform and cyclic. Now in Ukraine there is a situation when without innovations and innovative technologies are not possible to solve all pressing problems, particularly in the tourism industry. 
Literature review. Research of innovative processes in various sectors of the economy devoted a large number of works both in Ukraine and abroad. Released a series of publications on issues of innovations in tourism: Akaev A.A. (2008), M.A. Izotova (2010), A.M. Kleymonov (2004), N.N. Malakhova, D.S. Ushakov (2008), V.A. Molchanova (2008), V.S. Novikov (2007), Mykhaylichenko H.I. (2012), but this issue is still considered insufficient.

Most researchers of innovative processes in tourism noted that tourism is an active consumer of technical innovations developed in other sectors: special tourist equipment based on advanced materials, climate control systems in hotels, electronic guides, satellite navigators, computer systems management and accounting, e-advertising and commerce. However, the question about whether the companies of tourism industry engaged innovation on their own and that is assume an innovation in tourism, remains open (Molchanova, 2008). Essentially, the problem is narrowed to the availability of service innovations in tourism, which is not quite justified, because the tourism industry is a diversified industrial complex. Besides the typical service enterprises (enterprises with accommodation and meals for tourists, transport companies, travel agencies, etc.), the tourism industry also includes the production sector enterprises (production of tourist equipment and inventory sporting goods, clothing for recreation and tourism, souvenirs, etc.). Innovations directly in service sector (service innovations) can be defined as a new concept of service, new channels of communication with clients, new systems of distribution and technology solutions that are often jointly changing offer services on the market, update functions of the company and require structurally new organizational, technological and human capabilities (Van Ark B., 2003).

Many American researchers under innovations understand the processes of emergence, development, distribution and changes of scientific and technical innovations in various spheres of human activity. For example, scientist W. Thompson (2001) states that: "Innovation is the generation, adoption and implementation of new ideas, processes, products and services". J. Schumpeter (1982) interprets innovation as new scientific and organizational combination of production factors created by entrepreneurial spirit. It was J. Schumpeter who first introduced in the scientific lexicon the term "innovation", which means "the embodiment of scientific discovery, technological invention in a new technology or a new kind of product." Moreover, J. Schumpeter considered innovation as a new function of production, "its new combination" (Schumpeter, 1982).

Ukrainian scientist Mykhaylichenko H.I. has formed the following definition of "innovation": - is a new technologies, products, services and their combinations, as 
well as the complex process of their creation, distribution and use to meet social needs (Mykhaylichenko H.I., 2012).

According to the definition of Broersma L. (Van Ark B., Broersma L., 2003), innovation is any idea (activity or material result) that is new by its qualitative characteristics compared to existing forms.

Scientist Novikov V.S. (Novikov, 2007) summarized the views of his colleaguesscientists identified innovation as follows: - is a created (improved), distributed and used products, technologies, services, solutions that are characterized by scientific and technical novelty and meet new social needs (Novikov, 2007).

We consider that the key to successful use of innovations in the activities of tourism industry enterprises are the source of origin of the idea of innovation. This source of ideas defines the scope of innovation and quality indicators of efficiency implementation.

Study case. Hotel and restaurant business belongs to the highly profitable sectors of the world economy, and in the XXI century has all chances to become a leading area in socio-economic development of Ukraine. International experience shows that a necessary prerequisite for successful penetration of this industry on state market is the tourism infrastructure. At the present stage of development it is tourism forms the economy of many countries, regions, destinations and is an important factor for sustainable development of the global hospitality industry. Despite the crisis, the number of tourists each year increases, according to forecasts of the World Tourism Organization in 2015 traveled every 7 inhabitant of the planet, accordingly expanding range of tourist services, increase the number and variety of routes, and the tourist becomes more demanding to service, to the conditions of accommodation, the number and variety of additional services in placing(Trends of hospitality industry, 2015).

The aim of the publication is to identify the main trends and directions of introduction of innovative technologies in the tourism industry.

To achieve goal of this article were used modern methods of research, particularly through systematic and analytical method done theoretical generalization of scientific concepts, developments, suggestions of scientists from Ukraine and other countries devoted to problems of implementation of innovative processes in tourism industry. Use of methods of logical generalization provides sequence of carrying scientific research. To solve specific tasks also were used the following methods: problem-indicative - for scientific substantiation of directions for solving management problems in the field of innovative development of tourist industry of Ukraine; comparative - to compare the processes of innovations implemented in the tourism industry in different regions and countries; praximetric - to analyse 
advanced scientific experience. Also were used the methods of complex systems analysis of economic and management phenomena and processes.

Innovations and innovative activities are traditionally presented as direction of scientific and technological progress (its high-tech component) and as a process, associated with the implementation of the results of scientific research and development into practice. However, the meaning of "innovation" is wider. The innovation sector is comprehensive; it not only covers the practical application of scientific and technological developments and inventions, but also includes changes in products, processes, marketing and organization. Innovation emerges as a clear factor of changes as a result of activities embodied in new or improved products, technological processes, new services and new approaches to meet social needs.(Akaev 2008, p. 28).

The term "innovation" describes the qualitative changes in the production process. Despite the fact that the term of "innovation" is widely used, until now there is no universally accepted definition of it. Various authors, such as P. Drucker (P. Drucker, 2007), J. Schumpeter (J. Schumpeter, 1982), interpret it depending on the object and subject of the study - as a result and as a process. Thus, innovation is the final result of innovative activity that got incarnation as a new or improved product introduced on the market, new or improved technological process used in practical activity or a new approach to social services.

The term "innovation" in its modern sense, was the first to apply by J. Schumpeter (1982), who emphasized that innovation is a significant change in production functions, is in a new compound and commercialization of new combinations based on the use of new materials and components, implementation of new processes, opening of new markets, introduction of new organizational forms.

Prospects of innovative development of Ukraine are largely dependent on the results of its cooperation with the European Union. The signing of the Association Agreement between Ukraine and the EU has become an important instrument for increased cooperation in innovative sphere and new format in the development of these relations. Thus in the Chapter 9 of this Agreement main emphasis is on the fact that the Parties shall develop and strengthen scientific and technical cooperation in order to increase their competitiveness. In Article 375 states that such cooperation will support Ukraine in the reform and reorganization of science management system and research institutions.

One of the motivating factors of the European integration development vector of Ukraine is the high innovative potential of the EU. Today the EU holds leading global positions in the development and implementation of many advanced technologies and high technology products and services. This integration with the EU will allow Ukraine to increase innovative potential. Today regional centres for 
cooperation with the EU are located in Lviv, Kharkiv, Zaporizhzhya, Odessa, Ivano-Frankivsk and Uzhhorod.

Ukraine is already today actively cooperating in the field of innovation with the EU and attached to participation in the framework programs that integrate all existing European initiatives on research and innovation. So in the period of 2003 to 2014 research institutions and higher educational institutions of Ukraine participated in 126 projects of the 7th Framework Programme with the amount financed by the European Commission in the amount of approximately 26.5 million Euros. In comparison, based on the result of participation in the 6th Framework Programme were 91 research project and nearly 6 million Euros financing. By the number of completed projects and amounts of their funding within implementation of the 6th and 7th Ukraine entered the top ten non-EU countries.

On the expediency of deepening Ukraine's integration with the EU demonstrate and high indicators of innovative development of its member countries in recent years. Today leaders of the EU by share of innovatively active enterprises are Ireland (74\% of the total number of enterprises), Denmark (71\%), Germany (69\%), Austria $(67 \%)$ and the Netherlands (62\%). Active market leaders in innovations are Sweden, Finland, Denmark, Germany and the United Kingdom. Low positions in the innovative sphere occupied countries that recently became the EU members, namely Slovenia, Czech Republic and Bulgaria. Among the EU member states a minimal indicators of innovative activity have Greece $-29 \%$ and Portugal $-26 \%$. However, given indicators are in 2 times higher than in Ukraine. Generally, the gap between the EU member states and Ukraine in terms of innovative activity amounts to $4-4,5$ times.

In the report "Global Innovation Index" 2016 of Cornell University, USA, French business school INSEAD and the World Intellectual Property Organization at the United Nations submitted effectiveness rating of innovative activity in 128 countries of the world based on 82 indicators (Fig. 1.) (Global Innovation Index Report 2016).

According to this ranking of the most innovative country is recognized Switzerland for the sixth time. Second place was taken by Sweden and the third by United Kingdom. Next - the USA, Finland and Singapore; to the number of 25 progressive countries joined China, Russia on the 43 place, Moldova - 46, Croatia - 47, Romania - 48, Ukraine - 56 (in 2014 was on 64). However, the "innovative gap" between developed countries and developing countries is remains, while promoting of innovations is an important factor in the development of economy competitiveness. 


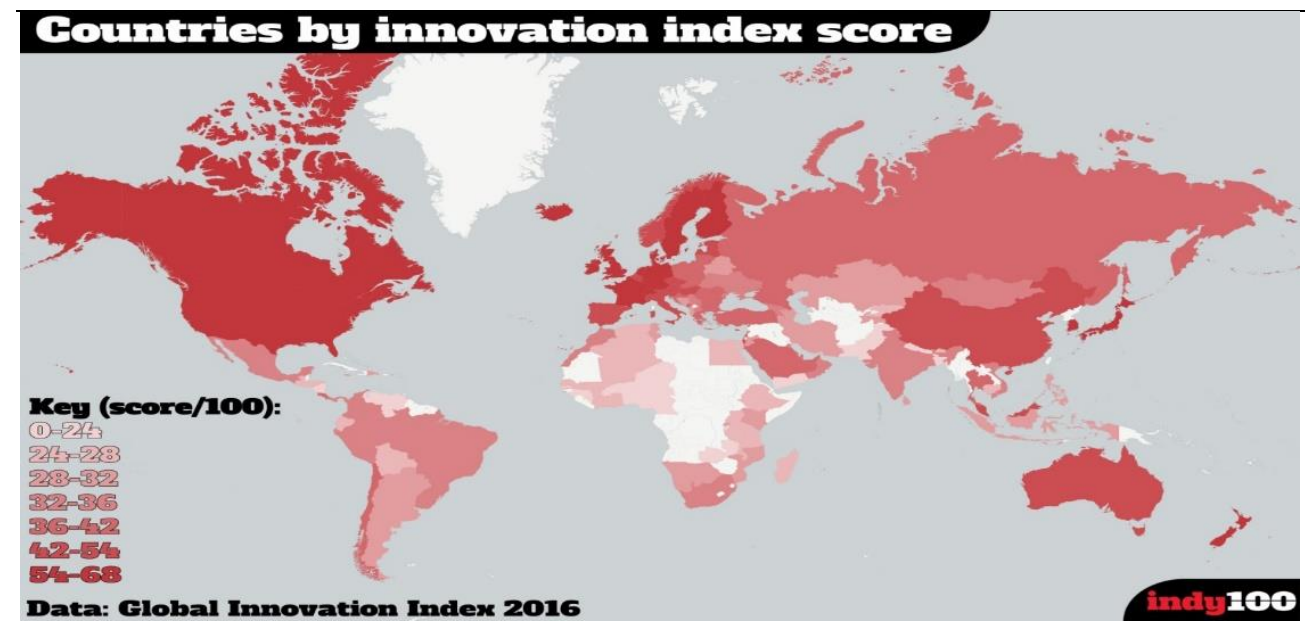

Fig.1.Interpretation of rating countries of Global Innovation Index in 2016 (Global Innovation Index Report, 2015)

Innovations require continuous investment. Before the crisis in 2009, spending on scientific researches grew up on the 7\% a year. Published data in the report "Global Innovation Index" 2016 indicate that in 2014 spending on scientific researches around the world grown up by only $4 \%$. This was the result of slower economic growth in countries with emerging economies and reducing spending on scientific researches in countries with high income.

Fundamental importance for the tourism industry has indicators of indexes: global adaptation index and sustainable development index. Let us present the results of calculating the index of sustainable development, which has the amount of indicators - economic, environmental and social with corresponding significant coefficients Fig.2.

According to the calculations, in 2015 the index of sustainable development of Ukraine amounted to 0,4 (maximum USA, South Korea, Finland, Iceland - 1,1; Romania, Slovakia, Poland, Lithuania, Bulgaria - 0,3; minimum - Malta, Latvia). The study of trends and patterns of integrated development of innovation, positive outcomes planning and management is a complex methodological problem in the tourism industry, associated primarily with the classification of innovations. 
Donysche-Medyanik A., Klyap M. (2017)

Introduction of innovations in the tourism industry: experience of Ukraine

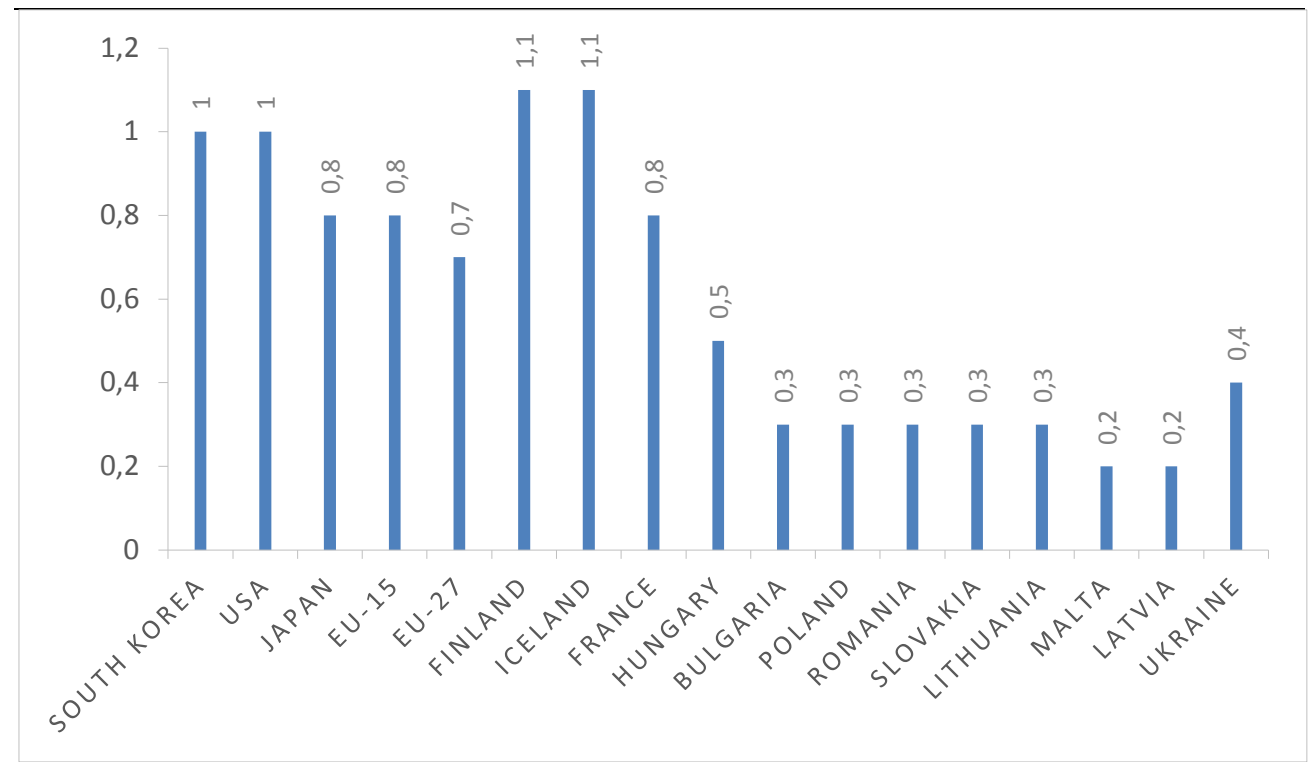

Fig.2. Calculation of the sustainable development index of countries * - development of author

As important to determine the essence of innovations in tourism are the following classification signs (Fig.3.):

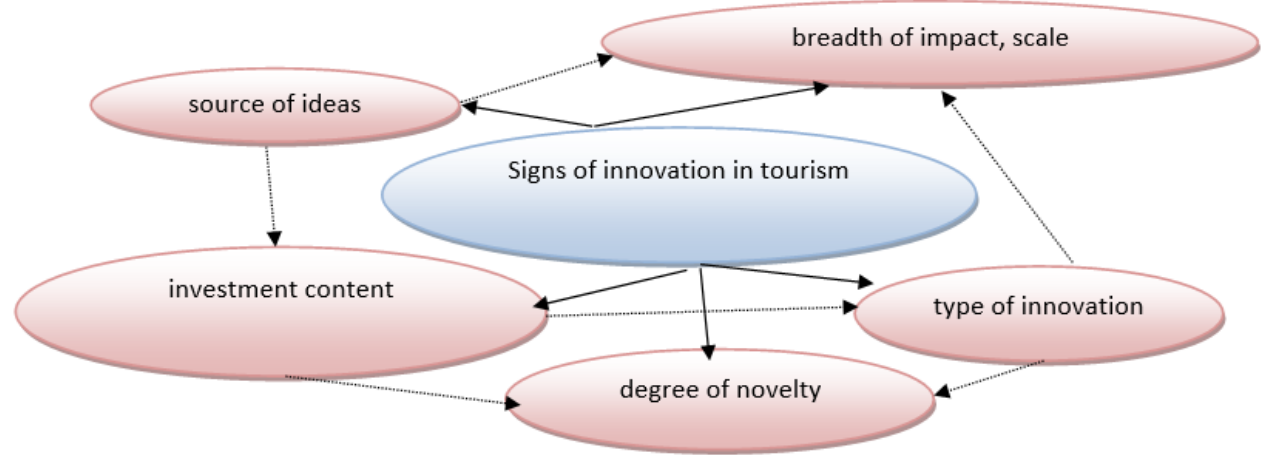

Fig.3. Classification signs of essence of innovation in tourism* * - development of author

- source of ideas (the needs of tourists, discoveries, inventions);

DE GRUYTER OPEN
Studia Universitatis "Vasile Goldis" Arad. Economics Series Vol 27 Issue 1/2017 ISSN: 1584-2339; (online) ISSN: 2285 - 3065 
- type of innovation (infrastructure of tourism, tourism product, ways and means of distribution of tourism product / services, control factors of production)

- degree of novelty

- breadth of impact, scale, consistency (local, global, system);

- investment content (low capital investment, capital-intensive) (Novikov V.S., 2007).

Ukrainian scientific Mykhaylichenko H.I. (Mykhaylichenko H.I., 2012) systematized and provided the following types of innovations (by application subject):

- innovation-product (innovation in the form of fundamentally new or improved product, which moves in the form of goods on the market);

- innovation-process (it's technical, production and management improvement that reduces the cost of production of the product);

- innovation-service (innovation related to service processes of the product use outside the enterprise (software of technological processes));

- intellectual capital (human resources as intellectual, creative elite, able to creatively perceive and modify unconventional management solutions);

- marketing innovations (introduction of a new method of sale, including significant changes in the design of the product, its market promotion or appointment of the new prices aimed at better meeting the needs of customers, open new markets, or meet new positions for the products of enterprise on the market in order to increase sales volume);

- organizational innovations (introduction of a new organizational method in activities of enterprises in the organization of workplace or external relations).

In our opinion, innovations in tourism should be seen as systemic measures having quality novelty, which leads to positive changes that ensure sustainable operation and development of the industry in the region. Thus, the idea of the creation and implementation of tourism projects that do not generate substantial profits at first, may give impetus to the development of tourism and thus actively contribute to the creation of additional jobs and rising incomes of people.

Innovation process in tourism is quite specific. It can give a positive effect only when, on the one hand, there are successful in the tourism market and meet the needs of customers, and on the other hand, is suitable for tourism organizations and management bodies of industry in the region and local authorities to make such common positive solutions which would has met the needs of the local population. Only such interaction of all elements (subjects and objects) of innovative process can lead to significant synergetic effect, expressed as growth (development) of the tourism industry.

The main principles of innovations in tourism include:

22 DE GRUYTER OPEN
Studia Universitatis "Vasile Goldis" Arad. Economics Series Vol 27 Issue 1/2017 ISSN: 1584-2339; (online) ISSN: $2285-3065$

Web: publicatii.uvvg.ro/index.php/studiaeconomia.Pages $15-28$ 
1. The scientific principle, which is to use scientific knowledge and methods to implement innovations to meet the needs of tourists.

2. The systemic principle. Developed strategy of innovative development the tourism industry in the region must take into account the factors and conditions necessary to meet the needs of people in the rest; resource opportunities of the region (economic, financial, human and other); social impact on society.

3. The principle of accordance of innovations to needs of tourists.

4. The principle of positivity results that is prevention of foolish, not deliberate creation and implementation of innovation that can be dangerous firstly, for the tourist; second, to a particular enterprise; thirdly, for biosphere and society as a whole.

5. The principle of immanence of investment process. To conduct necessary research, development and innovation materialize used investment resources, the effectiveness of which is determined by the degree of importance and scale of innovation.

6. Compliance of innovative activity and its results (innovations) to the level of society development.

7. The principle of consistency. The process of innovation ends with appearance on the market a product that must at some stage of its life cycle cause requirements (to stimulate the idea) for creating the next innovation and provide financial support for this process.

8. The principle of security. Any innovation should ensure the absence of damage to humans and its environment (Novikov, 2007, p. 124).

In modern market conditions, innovations in hotel business are compulsory process for each placement agent who wants to keep regular visitors and attract new ones. Traveling around the world and visiting various hotels, visitors and tourists have become more demanding and to be "in the game" hotels should consider this phenomenon.

Therefore hospitality industry never ceases to amaze by active implementation of innovative technologies and marketing strategies. On the introduction of innovative processes in Ukraine affects the political and economic situation, social situation of citizens, national legislation, and international agreements.

Thus we define the following reasons of innovations implementation in the studied area:

- saturation and super saturation of market of hotel services by typical means of accommodation;

- there is a risk of loss of market share in the occupied territories;

- increased competition and growth proposals; 
- technological revolution and the expansion of the use of information technology;

- transition from economic proposals to the economy of supply and service economy. (Saak A.E., 2007)

Development of innovative activity in Ukraine occurs in the following areas (Fig.4.):

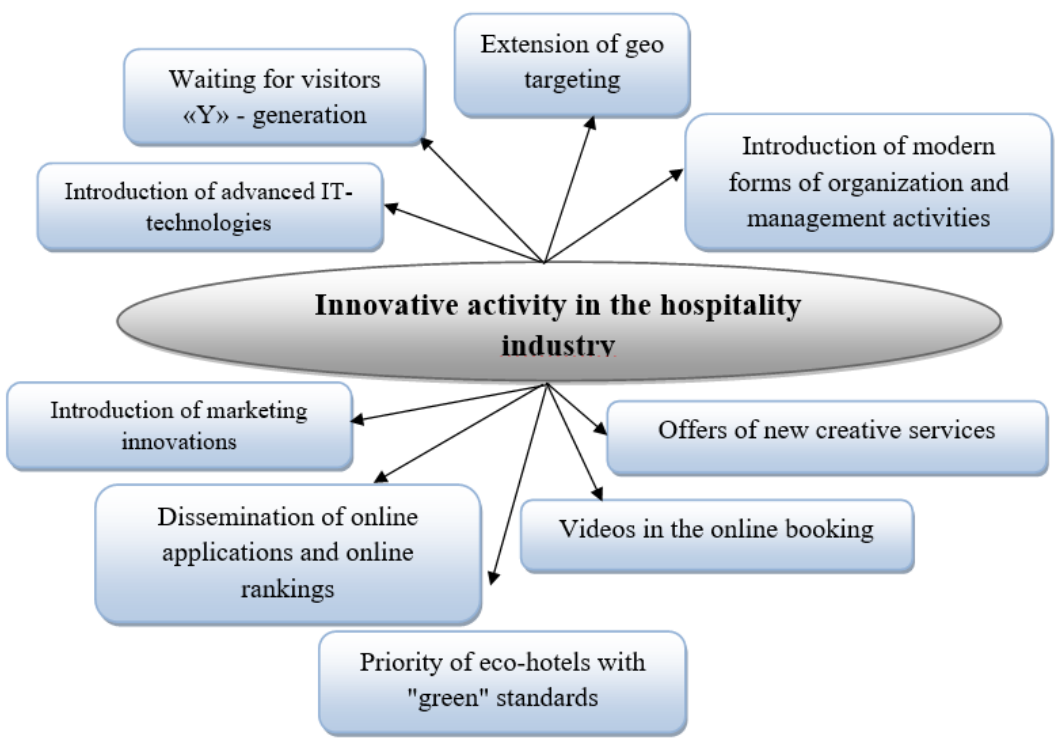

Fig.4. Directions of introduction of innovative technologies in the hospitality industry*

$$
\text { * - development of author }
$$

- Marketing innovations that are designed to meet the needs of target consumers and attract visitors from not covered segment at the current moment.

- Temporary (periodic) innovations aimed at changing the qualitative properties of services (implementation of new, creative services), their market positioning as exclusive, which involve increasing competitive advantage.

- Introduction of innovative processes in the hotel and restaurant business to attract innovations related to enterprise development and the hospitality industry and in management structure, including reorganization and acquisitions of competitors; personnel policies (update staff, improve their skills); rational economic and financial activities (introduction of modern forms of accounting reporting).

24 DE GRUYTER OPEN
Studia Universitatis "Vasile Goldis" Arad. Economics Series Vol 27 Issue 1/2017 ISSN: 1584-2339; (online) ISSN: 2285 - 3065

Web: publicatii.uvvg.ro/index.php/studiaeconomia.Pages $15-28$ 
- Extension of geo targeting is a trend toward individualization of work with the Internet audience. Geo targeting (the word «geo targeting» English origin and literally means in web development and internet marketing) is a method of informing visitors about its environment, according to its geographical location. Thus regional binding of the site allows reconfigure content for different regions. For example, Googleuses regional bind to redirect users to www.google.com in specific domains of individual countries, and this change over IP is considered acceptable practice (Geo Targeting., ru.wikipedia.org).

Western experts (Trends of hospitality industry, 2015) expect an increase of popularity among methods of geo targeting marketing among hoteliers who root for increasing the effectiveness of marketing budgets. Restructuring of the hotels site content and advertising messages depending on the regional finding of the user increases the possibility of involvement.

- Waiting for visitors «Y»- generation. In 2016 significantly increase the number of travelers belonging to the Millennium generation, generation of so-called «Y», something that will change the market situation. As this generation of people born after 1981 and entered the new millennium at a young age, which is characterized above all enthusiasm digital technology. Guests generation «Y» characterized by a deep interest and involvement in digital technology, they are quite tempted and expect a fundamentally new quality of service. Their habits instantly share experiences and evaluate services on the Internet and social networks will depend on the position of the hotel in the market.

- Use video when booking online. Browse photos, for hotel guests are insufficient even formatted as panoramic shooting. A decision to guests booking a place they want to see their future placement of maximum volume, detail and close to reality. Therefore, the presence of 3D-video trial round at the hotel will soon become a necessity, as it is now - pictures of interior rooms.

- The spread of online applications and online rankings. The growing number of mobile applications and their integration into everyday life will increase, and with it increased importance of online ratings of hotels and restaurants. Therefore, do not underestimate the power of comments posted on the Internet, at school or on forums, social networks, since a large number of people form their opinion from reading and can significantly affect the load and the hotel or restaurant.

- Priority of eco-hotel with "green" standards. The innovative concept of hospitality - an eco-hotel provides dependence of institutions on the environment, ecological sustainability, contribution to environmental conservation, environmental training program, taking into account local culture, adherence to strict "green" principles in order to give visitors confidence that were in safe non- 
toxic and energy efficient housing. Relevance of accommodation, which supports eco-concept, is becoming increasingly popular among visitors because of pure natural areas, compliance of hotel for balanced environmental policy. Interest in "green" standards not goes out of style; it stays in consciousness of consumers and becomes a priority. Research of benefits 1,300 respondents conducted by the popular website TripAdvisor, found that $62 \%$ of visitors "often" or "always" thinking about ecology, choosing a hotel or restaurant (Geo Targeting, ru.wikipedia.org).

Thus, innovations in the hospitality industry are the systematic measures that have quality novelty that lead to positive changes in the industry. Innovative process gets its recognition by the market of hospitality and customer satisfaction and by adopting common solutions of hotel and restaurant enterprises with authorities at different levels.

One of the main ways to attract new customers in accommodation establishments is to offer them new services. Consider the innovation inherent in the hotel and restaurant business in the modern conditions. According to the research among introduced advanced services should be allocated Sleepbox (capsule), digital multimedia technology Digital Signage (digital signage), and new technology "Teleport" from the hotel network "Marriott".

One of the problems of modern tourism in Ukraine is the lack in the city centers good hotels for a small fee. Of course, it is possible to stay in inexpensive hostels, but the downside of their location is the distance from the city center, on the outskirts of the city, which hinders the mobility of tourists. For the most part, tourists stop in hostels, whose budget is very limited (young people, students). This contingent of tourists prefers amateur tourism or prefers informative tours in order that the share of free time would be bigger. And the place of their accommodation must be not too far from the city center.As an alternative for tourists who do not want to pay more or settle in hotels in the outskirts of the city is the "capsule hotel" - one of the variants of Japanese hotels, which are small sleeping cells, placed one above the other. They are located primarily at big railway stations or near the entertainment districts for convenient location of visiting people. A room in a capsule hotel is a capsule with the size approximately $2 \times 1 \times 1,25 \mathrm{~m}$. For installation of Sleepbox cabins, in our opinion, it is advisable to provide in a quiet area of the airport, on the territory of railway stations, exhibition and recreational complexes, shopping centers. Eventually this type of temporary accommodation may become popular, especially among young people, or people who come to the city for a short time. We believe that Ukraine should try a new capsule hotel, and it will become an incentive in the development of modern hospitality industry. (Veres K., 2015) 
To the innovative processes taking place in the hotel industry belongs technology Digital Signage (digital signage) - an effective tool to attract and retain the attention of guests to hotel services. With Digital Signage can show exciting video that promotes a welcoming atmosphere and fine dining restaurant of the hotel. In a few seconds it can decide the future dining place of the hotel visitor directly at reception. While guests accommodated in the room this technology allows orienting him in the right direction. Digital Signage Technology improves communication with the visitor, unlike traditional marketing materials; this process can be automated for transmitting the right information at the right time and in many places at the same time (Trends of hospitality industry, 2015). We believe that the introduction of Digital Signage technology will solve the problem to improve the quality and speed of service hotel guests, increased sales of additional services and optimize marketing costs.

Conclusions. Thus, innovative activities in the tourism industry aimed at creation of new or modifications of existing product, familiarization of new markets, introduction of advanced IT-technologies and modern forms of organization and management activities. It is therefore innovations in tourism are necessary and essential condition of its development. One of the main ways to attract consumers and increase income, is to offer them a new product (service).In the tourism industry, this product can be new routes or places of recreation. However, in almost every travel agency, hotel has the fear to be first in using innovations. Innovations bring with them considerable risk. For example, an effective innovation that makes a profit - booking of tours via on-line service saves time, speeds up the processing of applications and confirming the chosen tour. Not all customers enjoy this service, not all using it, but it is observed an automation of the industry.

Management of innovations and their introduction to the development of the hospitality industry - these questions are basic and the most important in this area. Thus, innovations in the tourism sector aimed at creating new or modifying existing product, to improve transport, accommodation and other services, development of new markets, the introduction of advanced information and telecommunication technologies and modern forms of organization and management activities.

\section{References}

1. Mensh H. Technological path. Research of H. Mensh. [Electronic resource]. Access:http://www.managerhelp.org/hoks-1458-1.html.

2. Akaev A.A. Modern financial and economic crisis in the light of the theory of innovation and technological development of the economy and management of the innovation process 
// Monitoring of global and regional markets 2008/2009 [Electronicresource]. - Access: http://cliodynamics.ru/index. php?id=167\&option=com_content\&task=view.

3. Izotova M.A. Innovations in socio-cultural service and tourism: a tutorial / M.A. Izotova, Y.A. Matyukhina. - M.: The Soviet sport, 2010.

4. Kleymonov A.M.Innovative processes in the development of the tourism / A.M. Kleymonov, B.I. Sergeev // Culture of the Black Sea people. - 2004. - №52, Volume 2. P.62-66.

5. MalakhovaN.N. Innovationinthetourismandservice / N.N. Malakhova, D.S. Ushakov. M.: ICC "MarT"; Rostovn/D: PublishingCenter "MarT", 2008.

6. Molchanova V.A. Innovation in tourism: definition, characteristics, classification / V.A. Molchanova // Mater. scientific-practical. Conf. "Problems of sustainable development of recreational areas". - Sochi: RIO JRC RAS, 2008. - P.62-69.

7. Novikov V.S. Innovation in tourism: study manuals for university students / V.S Novikov. - M.: Publishing Center "Academy", 2007.

8. Van Ark B., Broersma L. and den Hertog, P. (2003) Services Innovation, Performance and Policy: A Review, Synthesis Report in the Framework of the Structural Information Provision on Innovation in Services, DIALOGIC and Innovation studies, Utrecht University.

9. J. Schumpeter. The Theory of Economic Development: A study of business profits, capital, credit, rate and cycle conditions: Tr. from Ger. V.S. Avtonomova. - M.: Progress, 1982.

10. DruckerP.F. - Business and innovations. M.: 2007.

11. Geo Targeting [Electronic resource] - Access: https://ru.wikipedia.org/wiki/ Геотаргетинг/

12. Trends of hospitality industry in the next year. [Electronic resource]. - Access: http://station-hotels.ru/uk/blog/88-trendy-industrii-gostepriimstva-v-budushchem-godu

13. Veres K.O. Low Cost Hotels: foreign experience. // International Scientific and Practical Conference "Hotel and restaurant business: innovative directions of development", 25 - 27 March 2015. - K.: NUFT, 2015. [Electronic resource]. - Access: http://dspace.nuft.edu.ua/ jspui/handle/ 123456789/19935.

14. Saak A.E., Pshenychnykh Y.A. Management in socio-cultural service and tourism. Study manual. - SPb .: St.Petersburg, 2007.

15. Global Innovation Index Report2016 [Electronic resource]. - Access: http://www.euroosvita.net/index.php/?category=1\&id=4887.

16. Mykhaylichenko H.I. Innovative tourism development: monograph / H.I. Mykhaylichenko; KNTEU. - K: KNTEU, 2012. 